\title{
Legalização das drogas e liberdade de expressão
}

Supremo Tribunal Federal (STF)

\section{ARGUIÇÃO DE DESCUMPRIMENTO DE PRECEITO FUNDAMENTAL 187 DISTRITO FEDERAL}

Voto

(s/mérito)

O SENHOR MINISTRO CELSO DE MELLO - (Relator): $\underline{\text { Superados os }}$ aspectos preliminares que venho de mencionar, passo $\underline{\text { a }} \underline{\text { analisar a pretensão }}$ deduzida na presente arguição de descumprimento de preceito fundamental.

Antes de fazê-lo, contudo, desejo enfatizar que este processo de controle de constitucionalidade não tem por objetivo discutir eventuais propriedades terapêuticas ou supostas virtudes medicinais ou , ainda, possíveis efeitos benéficos resultantes da utilização de drogas ou de qualquer substância entorpecente específica, mas, ao contrário, busca-se, na presente causa, proteção a duas liberdades individuais, de caráter fundamental: de $\underline{\mathrm{um}} \underline{\mathrm{lado}}$, a liberdade de reunião e, de outro, o direito à livre manifestação do pensamento, em cujo núcleo acham-se compreendidos os direitos de petição, de crítica, de protesto, de discordância e de livre circulação de ideias. 


\section{O direito de reunião e a liberdade de manifestação do pensamento: dois importantes precedentes do Supremo Tribunal Federal}

Postula-se, nesta arguição de descumprimento de preceito fundamental, seja dado, ao art. 287 do Código Penal, interpretação conforme à Constituição, "de forma a excluir qualquer exegese que possa ensejar a criminalização da defesa da legalização das drogas, ou de qualquer substância entorpecente específica, inclusive através de manifestações e eventos públicos" (fls. 14 - grifei).

Tenho para mim, Senhor Presidente, que o Supremo Tribunal Federal defronta-se, no caso, com um tema de magnitude inquestionável, que concerne

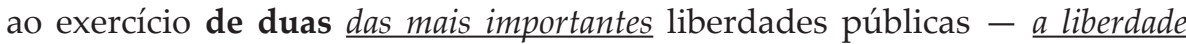
de expressão $\underline{\text { e a liberdade de reunião }}$ - que as declarações constitucionais de direitos e as convenções internacionais - como a Declaração Universal dos Direitos da Pessoa Humana (Artigos XIX e XX), a Convenção Americana sobre Direitos Humanos (Arts. 13 e 15) e o Pacto Internacional sobre Direitos Civis e Políticos (Artigos 19 e 21) - têm consagrado no curso de um longo processo de desenvolvimento $\underline{\mathbf{e}}$ de afirmação histórica dos direitos fundamentais titularizados pela pessoa humana.

É importante enfatizar, Senhor Presidente, tal como tive o ensejo de assinalar em estudo sobre "O Direito Constitucional de Reunião" (ㅍT)SP vol. 54/19-23, 1978, Lex Editora), que a liberdade de reunião traduz meio vocacionado ao exercício do direito à livre expressão das ideias, configurando, por isso mesmo, um precioso instrumento de concretização da liberdade de manifestação do pensamento, nela incluído o insuprimível direito de protestar.

Impõe-se desse modo, ao Estado, em uma sociedade estruturada sob a égide de um regime democrático, o dever de respeitar a liberdade de reunião (de que são manifestações expressivas o comício, o desfile, a procissão e a passeata), que constitui prerrogativa essencial dos cidadãos, normalmente temida pelos regimes despóticos ou ditatoriais que não hesitam em golpeála, para asfixiar, desde logo, o direito de protesto, de crítica e de discordância daqueles que se opõem à prática autoritária do poder.

Guardam impressionante atualidade, Senhor Presidente, as palavras que RUY BARBOSA, amparado por decisão desta Corte, proferiu, em 12 de abril de 1919, no Teatro Politeama, em Salvador, durante campanha presidencial por ele disputada, em conferência cuja realização só se tornou possível em virtude de "habeas corpus" que o Supremo Tribunal Federal lhe concedera, tanto 
em seu favor quanto em benefício de seus correligionários, assegurando-lhes $\underline{O}$ pleno exercício da liberdade de reunião e do direito à livre manifestação do pensamento, indevidamente cerceados por autoridades estaduais que buscavam impedir que o grande político, jurisconsulto e Advogado brasileiro divulgasse a sua mensagem e transmitisse as suas ideias ao povo daquele Estado, com o objetivo de conquistar seguidores e de conseguir adesões em prol de sua causa, valendo reproduzir, no ponto, a seguinte passagem daquele pronunciamento:

Venho, senhores, de Minas, venho de S. Paulo (...). De S. Paulo e Minas, onde pude exercer desassombradamente os direitos constitucionais, as liberdades necessárias de reunião e palavra, franquias elementares da civilização em tôda a cristandade. De Minas e S. Paulo, cujos governos, contrários ambos à minha candidatura, nenhum obstáculo suscitaram ao uso dessas faculdades essenciais a tôdas as democracias, a tôdos os regimens de moralidade e responsabilidade: antes abriram, em volta dos comícios populares, em tôrno da tribuna pública, um círculo de segurança e respeito, em que as nossas convicções se sentiam confiadas nos seus direitos e os nossos corações orgulhosos do seu país. De S. Paulo e Minas, em suma, onde o respeito da autoridade ao povo, e a consideração do povo para com a autoridade, apresentavam o espetáculo da dignidade de uma nação obediente às suas leis e governada pela soberania.

Venho dêsses dois grandes Estados, para uma visita a êste outro não menor do que êles na sua história, nas virtudes cívicas dos seus habitantes, nos costumes da sua vida social, venho, também, a convite da sua população; e, com que diversidade, com que contraste, com que antítese me encontro! Aqui venho dar com o direito constitucional de reunião suspenso. Por quem? Por uma autoridade policial. Com que direito? Com o direito da fôrça. Sob que pretexto? Sob o pretexto de que a oposição está em revolta, isto é, de que, contra o govêrno, o elemento armado e o Tesouro juntos estão em rebeldia os inermes, as massas desorganizadas e as classes conservadoras.

Banido venho encontrar, pois, o direito de reunião, ditatorialmente banido. Mas, ao mesmo tempo, venho encontrar ameaçada, também soberanamente, de proscrição a palavra, o órgão do pensamento, o instrumento de comunicação do indivíduo com o povo, do cidadão 
com a pátria, do candidato com o eleitorado. Ameaçada, como? Com a resolução, de que estamos intimados pelo situacionismo da terra, com a resolução, que, em tom de guerra aberta, nos comunicaram os nossos adversários, de intervir em tôdas as nossas reuniões de propaganda eleitoral, opondo-se à nossa linguagem (...).

Mas, senhores, os comícios populares, os 'meetings', as assembléias livres dos cidadãos, nas praças, nos teatros, nos grandes recintos, não são invento brasileiro, muito menos desta época (...). São usos tradicionais das nações anglo-saxônicas, e das outras nações livres. Tiveram, modernamente, a sua origem nas Ilhas Britânicas, e nos Estados Unidos. Dessa procedência é que os recebemos. Recebemolos tais quais eram. Com êles cursamos a nossa prática do direito de reunião. Com êles, debaixo do regímen passado, associamos a colaboração pública à reforma eleitoral, apostolamos e conseguimos a extinção do cativeiro. Com eles, neste regímen, não pouco temos alcançado para cultura cívica do povo. (...).

(...) $\mathrm{O}$ direito de reunião não se pronuncia senão congregando acêrca de cada opinião o público dos seus adeptos.

A liberdade da palavra não se patenteia, senão juntando em tôrno de cada tribuna os que bebem as suas convicções na mesma fonte, associam os seus serviços no mesmo campo, ou alistam a sua dedicação na mesma bandeira. A igualdade no direito está, para as facções, para as idéias, para os indivíduos, no arbítrio, deixado a todos sem restrição, de congregar cada qual os seus correligionários, de juntar cada qual os seus comícios, de levantar cada qual o seu apêlo, no lugar da sua conveniência, na ocasião da sua escolha, nas condições do seu agrado, mas separadamente, mas distintamente, mas desafrontadamente, cada um, a seu talante, na cidade, na rua, no recinto, que eleger, sem se encontrarem, sem se tocarem; porque o contacto, o encontro, a mistura, acabariam, necessàriamente, em atrito, em invasão, em caos. (grifei)

$\mathrm{O}$ alto significado que o direito de reunião assume nas sociedades democráticas foi acentuado, em tempos mais recentes, pelo Plenário do Supremo Tribunal Federal, no julgamento da ADI 1.969/DF, Rel. Min. RICARDO LEWANDOWSKI, quando esta Corte, em sessão de 28/06/2007, declarou a 
inconstitucionalidade do Decreto no 20.089/99, editado pelo Governador do Distrito Federal, que vedava "a realização de manifestações públicas, com a utilização de carros, aparelhos e objetos sonoros", em determinados locais públicos, como a Praça dos Três Poderes e a Esplanada dos Ministérios, em decisão que restou consubstanciada em acórdão assim ementado:

AÇÃO DIRETA DE INCONSTITUCIONALIDADE. DECRETO 20.098/99, DO DISTRITO FEDERAL. LIBERDADE DE REUNIÃO E DE MANIFESTAÇÃO PÚBLICA. LIMITAÇÕES. OFENSA AO ART. $5^{\circ}$, XVI, DA CONSTITUIÇÃO FEDERAL.

I. A liberdade de reunião e de associação para fins lícitos constitui uma das mais importantes conquistas da civilização, enquanto fundamento das modernas democracias políticas.

II. A restrição ao direito de reunião estabelecida pelo Decreto distrital 20.098/99, a toda evidência, mostra-se inadequada, desnecessária e desproporcional quando confrontada com a vontade da Constituição (Wille zur Verfassung).

III. Açãodiretajulgadaprocedenteparadeclararainconstitucionalidade do Decreto distrital 20.098/99. (grifei)

Cabe rememorar, neste ponto, Senhor Presidente, a importantíssima decisão, por mim anteriormente mencionada, que esta Suprema Corte proferiu há 92 (noventa e dois) anos, em 1919, nos autos do HC 4.781/BA, Rel. Min. EDMUNDO LINS, em cujo âmbito se buscava garantir, em favor de diversos pacientes, inclusive de Ruy Barbosa, o exercício do direito de reunião (e também, porque a este intimamente vinculado, o de livre manifestação de crítica ao Governo e ao sistema político, bem assim o direito de livremente externar posições, inclusive de não conformismo, sobre qualquer assunto), em comícios ou em encontros realizados em prol da candidatura oposicionista de RUY, que se insurgia, uma vez mais, contra as oligarquias políticas que dominaram a vida institucional do Estado brasileiro ao longo da Primeira República.

Nesse julgamento, o Plenário do Supremo Tribunal Federal concedeu ordem de "habeas corpus" em favor de RUY BARBOSA e de diversos outros pacientes, proferindo, então, decisão que assim foi resumida pela eminente Dra. LÊDA BOECHAT RODRIGUES (História do Supremo Tribunal Federal, vol. III/204-205, 1991, Civilização Brasileira): 
A Constituição Federal expressamente preceitua que a todos é lícito associarem-se e reunirem-se livremente e sem armas, não podendo intervir a polícia senão para manter a ordem pública. Em qualquer assunto é livre a manifestação do pensamento por qualquer meio, sem dependência de censura, respondendo cada um, na forma legal, pelos danos que cometer. Não se considera sedição ou ajuntamento ilícito a reunião (pacífica e sem armas) do povo para exercitar o direito de discutir e representar sobre os negócios públicos. À Polícia não assiste, de modo algum, o direito de localizar "meetings" e comícios. Não se concede "habeas-corpus" a indivíduo não indicado nominalmente no pedido. (grifei)

A inquestionável relevância desse julgado, essencial à compreensão da posição desta Suprema Corte em torno dos direitos fundamentais de reunião e de livre manifestação do pensamento, revelada sob a égide de nossa primeira Constituição republicana, impõe que se relembrem, por expressivas, algumas de suas passagens mais notáveis:

Efetivamente, depois de assegurar a todos os indivíduos o direito de se reunirem livremente e sem armas, o legislador constituinte definiu muito bem, a respeito, a função preventiva da polícia, verbis "não podendo intervir a polícia senão para manter a ordem pública" (art. $72, \S 8 \stackrel{\circ}{\circ}$.

Não pode também a polícia localizar os meetings ou determinar que só em certos lugares é que eles se podem efetuar, se forem convocados para fins lícitos, como na espécie:

1) porque isto importaria, afinal, em suprimi-los, pois bastaria que ela designasse lugares, ou sem a capacidade necessária à maior aglomeração de pessoas, ou habitualmente frequentados, apenas, por indivíduos de baixa classe, azevieiros ou frascários;

$2^{\circ}$ ) porque ninguém pode ser obrigado a deixar de fazer alguma coisa senão em virtude de lei (Const. Fed., art. $72, \S 1^{\circ}$ ); ora, não há lei alguma que prescreva que só se efetuem comícios em lugares previamente fixados pela polícia; e, ao contrário, o que a lei vigente preceitua é que "não se considera sedição, ou ajuntamento ilícito, a reunião do povo desarmado, em ordem, para o fim de representar contra as injustiças, 
vexações e mal procedimento dos empregados públicos; nem a reunião pacífica e sem armas de povo nas praças públicas, teatros e quaisquer outros edifícios ou lugares convenientes para exercer o direito de discutir e representar sobre os negócios públicos. Para o uso dessa faculdade, não é necessária prévia licença da autoridade policial que só poderá proibir a reunião anunciada no caso de suspensão das garantias constitucionais, limitada em tal caso, na ação de dissolver a reunião, guardadas as formalidades da lei e sob as penas nela cominadas" (Cod. Penal, art. 123 e parágrafo único).

Ora, não nos achamos com as garantias constitucionais suspensas.

E, entretanto o sr. Governador da Bahia expediu ao sr. Presidente da República um telegrama, em que lhe participa, com a mais cândida ingenuidade e como a coisa mais natural deste mundo e mais legal, que “o seu chefe de Polícia, dr. Alvaro Cóva, resolveu proibir o meeting anunciado para hoje, em que devia falar o dr. Guilherme de Andrade, a favor do Senador Epitácio Pessôa, e também quaisquer outros que fossem anunciados" (Jornal do Comércio, de 27 de março de 1919, a fls.).

“O dr. secretário da Polícia e Segurança Pública, a bem da ordem, deliberou não consentir na realização do meeting na Praça Rio Branco, que para hoje anunciou o sr. dr. Guilherme de Andrade, bem como qualquer que for convocado, não só para aquele local como para qualquer outro ponto, que embarace o trânsito e perturbe a tranquilidade pública" (fl.).

E ainda, em resposta às informações ora pedidas por este Tribunal, $\mathbf{o}$ dr. Governador da Bahia, depois de se referir aos sucessos do dia 25 de março, na praça Rio Branco, acrescenta que: "Secretário Segurança Pública resolveu não consentir realização comício na referida praça e em outras em idênticas circunstâncias" (fl.): é a prova provada do abuso do poder, da flagrante ilegalidade do procedimento do chefe de Polícia da Bahia e, pois, da violência iminente, temida pelo impetrante, assim, pois;

Considerando que a Constituição Federal expressamente preceitua que "a todos é lícito associarem-se e reunirem-se livremente e sem armas, não podendo intervir a polícia senão para manter a ordem pública. " (Art. 72, § 8º); 
Considerando que, em qualquer assunto, é livre a manifestação de pensamento pela imprensa ou pela tribuna, sem dependência de censura, respondendo cada um pelos abusos que cometer, nos casos e pela forma que a lei determina. (Art. supra citado, § 12).

Considerando que "não se considera sedição ou ajuntamento ilícito a reunião pacífica e sem armas do povo nas praças públicas, teatros e quaisquer outros edifícios ou lugares convenientes para exercer o direito de discutir e representar sobre os negócios públicos." (Cod. Penal, art. 123), exatamente o fim para que é impetrado o presente "habeas corpus";

Considerando, finalmente, que à polícia não assiste, de modo algum, o direito de localizar meetings ou comícios; porque, para o uso dessa faculdade (a supra transcrita) não é necessária prévia licença da autoridade policial, que só poderá proibir a reunião anunciada, no caso de suspensão das garantias constitucionais, (o que se não verifica na espécie) e ainda em tal caso, "limitada a sua ação a dissolver a reunião, guardadas as formalidades da lei e sob as penas nela cominadas". (Cod. Penal, parágrafo único do art. 123, supra transcrito).

Acordam, em Supremo Tribunal Federal, nos termos supra, conceder a presente ordem de 'habeas corpus' ao sr. senador Ruy Barbosa e a todos os indivíduos mencionados nominalmente na petição de fls. 2 e no princípio deste Acórdão, para que possam exercer, na capital do Estado da Bahia e em qualquer parte dele, o direito de reunião $\underline{\text { e }}$ mais, publicamente, da palavra nas praças, ruas, teatros e quaisquer recintos, sem obstáculos de natureza alguma, e com segurança de suas vidas e pessoas, realizando os comícios que entenderem necessários e convenientes à propaganda da candidatura do impetrante à sucessão do Presidente da República, sem censura e sem impedimento de qualquer autoridade local ou da União. (grifei)

É importante registrar, Senhor Presidente, nas palavras do saudoso e eminente Ministro ALIOMAR BALEEIRO ("O Supremo Tribunal Federal, esse outro desconhecido"), o caráter de significativa relevância que assumiu o julgamento que venho de mencionar, quando da concessão, por esta Suprema Corte, da ordem de "habeas corpus" que garantiu, aos cidadãos da República, no contexto histórico das já referidas eleições de 1919, o pleno exercício das liberdades fundamentais de reunião e de manifestação do pensamento: 
Dos longes do passado remoto, ligo o Supremo Tribunal Federal às reminiscências de meus $\mathbf{1 3}$ anos de idade, na Bahia. Minha velha cidade entrara em ebulição com a campanha presidencial de RUI BARBOSA e de EPITÁCIO PESSOA, em 1919. Tombaram gravemente feridos à bala, num comício, MEDEIROS NETTO e SIMÕES FILHO. PEDRO LAGO escapou, mas sofreu violências outras dos sicários. As vítimas eram amigos políticos e pessoais de meu pai e de meu avô. $\mathrm{O}$ meu irmão mais velho, ainda estudante de Direito, trabalhava no jornal oposicionista, alvo das ameaças policiais. Tudo isso aqueceu a atmosfera em nossa casa. Aliás, a Bahia toda ardia em febre partidária. Para os ruistas, tratava-se dum apostolado cívico e não duma querela de facções.

Temia-se pela vida do próprio RUI quando viesse a fim de pronunciar a conferência anunciada para breve. Suspeitava-se também do govêrno da República, porque afrontosamente mandara a fôrça federal desagravar a bandeira do edifício dos Correios, sob pretexto de que recebera ultraje dos partidários do candidato baiano.

Nesse clima eletrizado, caiu como um raio a notícia de que o Supremo Tribunal Federal concedera a RUI e seus correligionários ordem de "habeas corpus", para que se pudessem locomover, e reunir em comício. Notou-se logo a mudança de atitude da polícia local, que, murcha, abandonou a atitude de provocação. RUI desembarcou dum navio e o povo exigiu que o carro fosse puxado à mão, ladeiras acima, cêrca de $10 \mathrm{~km}$, até o bairro da Graça, em meio ao maior delírio da massa, que já presenciei. Assisti à saudação que lhe dirigiu, em nome da Bahia, no meio ao trajeto, o velho CARNEIRO RIBEIRO, de barbas brancas ao vento.

Não se via um soldado, nem um guarda civil nas ruas. Se um seabrista tentava provocar incidentes, logo alguém intervinha para " não perdermos a razão no Supremo Tribunal". A população prêsa da exaltação partidária mais viva manteve a maior rigorosa ordem, durante dias sem policiamento, a despeito das expansões emocionais.

Ouvi, sem perder uma palavra, ao lado de meu pai, no Politeama baiano, a longa conferência do maior dos brasileiros, interrompida, de minuto a minuto, por tempestades de aplausos. Logo, nos primeiros momentos, Rui entoou um hino ao Supremo Tribunal, que possibilitara a todos o exercício do direito de reunião pacífica naquele 
momento. Rompeu um côro ensurdecedor de vivas à Côrte egrégia. Foi assim que tomei consciência do Supremo Tribunal Federal e de sua missão de sentinela das liberdades públicas, vinculando-o a imagens imperecíveis na minha memória. E também na minha saudade. (grifei)

Tais palavras, Senhor Presidente, mostram a reverência e a veneração que RUY, ALIOMAR BALEEIRO e os defensores da causa da liberdade sempre dedicaram a esta Suprema Corte, nela reconhecendo o caráter de uma instituição essencialmente republicana, fiel depositária do altíssimo mandato constitucional que lhe foi atribuído pelos Fundadores da República, que confiaram, a este Tribunal, a condição eminente de guardião da autoridade, de protetor da intangibilidade e de garante da supremacia da Lei Fundamental.

As decisões que venho de referir, Senhor Presidente - uma, pronunciada sob a égide da Constituição republicana de 1891 (HC 4.781/BA, Rel. Min. EDMUNDO LINS), e outra, proferida sob a vigente Constituição promulgada em 1988 (ADI 1.969/DF, Rel. Min. RICARDO LEWANDOWSKI) - , bem refletem, ainda que as separe um espaço de tempo de quase um século, o mesmo compromisso desta Suprema Corte com a preservação da integridade das liberdades fundamentais que amparam as pessoas contra o arbítrio do Estado.

$N a$ realidade, esses julgamentos revelam o caráter eminente da liberdade de reunião, destacando-lhe $o$ sentido de instrumentalidade de que ele se reveste, $\underline{a} \underline{0}$ mesmo tempo em que enfatizam a íntima conexão que existe entre essa liberdade jurídica e o direito fundamental à livre manifestação do pensamento.

O Supremo Tribunal Federal, em ambos os casos, deixou claramente consignado que o direito de reunião, enquanto direito-meio atua em sua condição de instrumento viabilizador do exercício da liberdade de expressão, qualificando-se, por isso mesmo, sob tal perspectiva, como elemento apto a propiciar a ativa participação da sociedade civil, mediante exposição de ideias, opiniões, propostas, críticas e reivindicações, no processo de tomada de decisões em curso nas instâncias de Governo.

É por isso que esta Suprema Corte sempre teve a nítida percepção de que há, entre as liberdades clássicas de reunião e de manifestação do pensamento, de um lado, e o direito de participação dos cidadãos na vida política do Estado, de outro, um claro vínculo relacional, de tal modo que passam eles a compor um núcleo complexo e indissociável de liberdades e de prerrogativas político-jurídicas, o que significa que o desrespeito ao direito de reunião, por parte do Estado e de seus agentes, traduz na concreção desse gesto de arbítrio, inquestionável transgressão às demais liberdades cujo exercício possa supor, para realizar-se, 
a incolumidade do direito de reunião, tal como sucede quando autoridades públicas impedem que os cidadãos manifestem, pacificamente, sem armas, em passeatas, marchas ou encontros realizados em espaços públicos, as suas ideias e a sua pessoal visão de mundo, para, desse modo, propor soluções,expressar o seu pensamento, exercer o direito de petição $\underline{\mathbf{e}}$, mediante atos de proselitismo, conquistar novos adeptos e seguidores para a causa que defendem.

A praça pública, desse modo, desde que respeitado o direito de reunião, passa a ser o espaço, por excelência, do debate, da persuasão racional, do discurso argumentativo, da transmissão de ideias, da veiculação de opiniões, enfim, a praça ocupada pelo povo converte-se naquele espaço mágico em que as liberdades fluem sem indevidas restrições governamentais.

Não foi por outra razão, Senhor Presidente, que o eminente Ministro MARCO AURÉLIO, quando do julgamento do pedido de medida cautelar na ADI 1.969/DF, ao fundamentar a concessão do provimento liminar, pôs em destaque $a$ indestrutível ligação que existe entre as liberdades públicas cuja proteção jurisdicional é requerida, uma vez mais, a esta Suprema Corte: “(...) o direito de reunião previsto no inciso XVI está associado umbilicalmente a outro da maior importância em sociedades que se digam democráticas: o ligado à manifestação do pensamento" (grifei).

Idêntica percepção foi revelada, no julgamento final da ADI 1.969/DF, pelo eminente Ministro RICARDO LEWANDOWSKI, Relator:

(...) Na verdade, o Decreto distrital 20.098/99 simplesmente inviabiliza a liberdade de reunião e de manifestação, logo na Capital Federal, em especial na emblemática Praça dos Três Poderes, "local aberto ao público", que, na concepção do genial arquiteto que a esboçou, constitui verdadeiro símbolo de liberdade e cidadania do povo brasileiro.

Proibir a utilização "de carros, aparelhos e objetos sonoros", nesse e em outros espaços públicos que o Decreto vergastado discrimina, inviabilizaria, por completo, a livre expressão do pensamento nas reuniões levadas a efeito nesses locais, porque as tornaria emudecidas, sem qualquer eficácia para os propósitos pretendidos. (grifei) 


\section{O direito fundamental de reunião: estrutura constitucional e oponibilidade de seu exercício ao Poder Público, cujos agentes estão sujeitos, em face dessa liberdade de ação coletiva, à estrita observância de limites e deveres de ordem jurídica}

O direito fundamental de reunião apoia-se, em nosso sistema de direito constitucional positivo, no inciso XVI do art. 5ำ da Constituição da República, que assim o proclama: "todos podem reunir-se pacificamente, sem armas, em locais abertos ao público, independentemente de autorização, desde que não frustrem outra reunião anteriormente convocada para o mesmo local, sendo apenas exigido prévio aviso à autoridade competente".

Trata-se de prerrogativa impregnada de caráter instrumental, qualificando-se, enquanto liberdade de ação coletiva, como importante meio de consecução e realização dos objetivos que animam aqueles que se congregam, para um fim específico, em espaços públicos ou privados.

A estrutura constitucional da liberdade de reunião autoriza que nela se identifiquem, pelo menos, 05 (cinco) elementos que lhe compõem o perfil jurídico:

a) elemento pessoal: pluralidade de participantes (possuem legitimação ativa ao exercício do direito de reunião os brasileiros e os estrangeiros aqui residentes);

b) elemento temporal: a reunião é necessariamente transitória, sendo, portanto, descontínua e não permanente, podendo efetuar-se de dia ou de noite;

c) elemento intencional: a reunião tem um sentido teleológico, finalisticamente orientado. Objetiva um fim, que é comum aos que dela participam;

d) elemento espacial: o direito de reunião se projeta sobre uma área territorialmente delimitada. A reunião, conforme o lugar em que se realiza, pode ser pública (vias, ruas e logradouros públicos) ou interna (residências particulares, v.g.);

e) elemento formal: a reunião pressupõe organização e direção, embora precárias. (grifei)

Qualquer que seja a finalidade que motive o encontro ou agrupamento de pessoas, não importando se poucas ou muitas, mostra-se essencial que a reunião, para merecer a proteção constitucional, seja pacífica, vale dizer, que se 


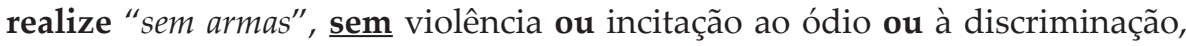
cumprindo ter presente, quanto a tal requisito, a advertência de PONTES DE MIRANDA (Comentários à Constituição de 1967 com a Emenda no 1 de 1969, tomo V/604, item n. 10, 2a ed./2a tir., 1974, RT), para quem

(...) a polícia não pode proibir a reunião, ou fazê-la cessar, pelo fato de um ou alguns dos presentes estarem armados. As medidas policiais são contra os que, por ato seu, perderem o direito a reunirem-se a outros, e não contra os que se acham sem armas. Contra esses, as medidas policiais são contrárias à Constituição e puníveis segundo as leis. (grifei)

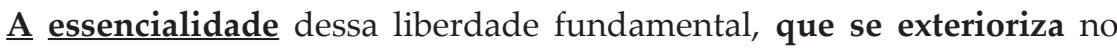
direito de qualquer pessoa reunir-se com terceiros, pacificamente, sem armas, em locais públicos, independentemente de prévia autorização de órgãos ou agentes do Estado (que não se confunde com a determinação constitucional de "prévio aviso à autoridade competente"), revela-se tão significativa que os modelos político-jurídicos de democracia constitucional sequer admitem que o Poder Público interfira no exercício do direito de reunião.

Isso significa que o Estado, para respeitar esse direito fundamental, não pode nem deve inibir o exercício da liberdade de reunião ou frustrar-lhe os objetivos ou inviabilizar, com medidas restritivas, a adoção de providências preparatórias e necessárias à sua realização ou omitir-se no dever de proteger os que a exercem contra aqueles que a ela se opõem ou, ainda, pretender impor controle oficial sobre o objeto da própria assembleia, passeata ou marcha.

É por tal motivo que a liberdade de reunião encontra veemente repulsa por parte de sistemas autocráticos, que não conseguem tolerar a participação popular nos processos decisórios de Governo nem admitir críticas, protestos ou reivindicações da sociedade civil.

É de ressaltar que, em nosso sistema normativo, o direito de reunião pode sofrer, excepcionalmente, restrições de ordem jurídica em períodos de crise institucional, desde que utilizados, em caráter extraordinário, os mecanismos constitucionais de defesa do Estado, como o estado de defesa (CF, art. 136, § 10, I, “a”) e o estado de sítio (CF, art. 139, IV), que legitimam a utilização, pelo Presidente da República, dos denominados poderes de crise, dentre os quais se situa a faculdade de suspender a própria liberdade de reunião, ainda que exercida em espaços privados.

Em período de normalidade institucional, contudo, essa liberdade fundamental, além de plenamente oponível ao Estado (que nela não pode 
interferir, sob pena de incriminação de seus agentes e autoridades, consoante prescreve, em norma de tipificação penal, a Lei no 1.207, de 25/10/1950), também lhe impõe a obrigação de viabilizar a reunião, assim como o dever de respeitar o direito - que assiste aos organizadores e participantes do encontro - à autônoma deliberação sobre o tipo e o conteúdo da manifestação pública.

É por isso, Senhor Presidente, que se pode identificar, na cláusula constitucional que ampara a liberdade de reunião ( $\underline{\mathbf{C F}}$ art. 5o, XVI), tanto um direito (titularizado pelos manifestantes) quanto uma obrigação (imposta ao Estado), tal como assinala PAULO GUSTAVO GONET BRANCO (Curso de Direito Constitucional, p. 443, item n. 3.1.4, 4- ed., 2009, Saraiva/IDP, em coautoria com Gilmar Ferreira Mendes e Inocêncio Mártires Coelho):

O direito de reunião engendra pretensão de respeito, não somente ao direito de estar com outros numa mesma coletividade organizada, mas também de convocar a manifestação, de prepará-la e de organizá-la. $\mathbf{O}$ direito de reunião exige respeito a todo processo prévio ao evento e de execução da manifestação. O Estado não há de interferir nesse exercício - tem-se, aqui, o ângulo de direito a uma abstenção dos Poderes Públicos (direito negativo).

O direito de reunião possui, de outra parte, um aspecto de direito a prestação do Estado. O Estado deve proteger os manifestantes, assegurando os meios necessários para que o direito à reunião seja fruído regularmente. Essa proteção deve ser exercida também em face de grupos opositores ao que se reúne, para prevenir que perturbem a manifestação. (grifei)

Vê-se, portanto, que a liberdade de reunião, tal como delineada pela Constituição, impõe, ao Estado, um claro dever de abstenção, que, mais do que impossibilidade de sua interferência na manifestação popular, reclama que os agentes $\underline{\mathbf{e}}$ autoridades governamentais $\underline{\text { não }}$ estabeleçam $\underline{\text { nem }}$ estipulem exigências que debilitem ou que esvaziem o movimento, ou, então, que lhe embaracem o exercício.

O Estado, por seus agentes e autoridades, não pode cercear nem limitar o exercício do direito de reunião, apoiando-se, para tanto, em fundamentos que revelem oposição governamental ao conteúdo político, doutrinário ou ideológico do movimento ou, ainda, $\underline{\text { invocando }}$, para restringir a manifestação pública, razões fundadas em mero juízo de oportunidade, de conveniência ou de utilidade. 
Disso resulta que a polícia não tem o direito de intervir nas reuniões pacíficas, lícitas, em que não haja lesão ou perturbação da ordem pública. Não pode proibi-las ou limitá-las. Assiste-lhe, apenas, a faculdade de vigiá-las, para, até mesmo, garantir-lhes a sua própria realização. $\mathbf{O}$ que exceder a tais atribuições, mais do que ilegal, será inconstitucional.

É dever, portanto, dos organismos policiais, longe dos abusos que têm sido perpetrados pelo aparato estatal repressivo, adotar medidas de proteção aos participantes da reunião, resguardando-os das tentativas de desorganizála e protegendo-os dos que a ela se opõem.

Por outro lado, conforme doutrina PONTES DE MIRANDA(Comentários à Constituição de 1967 com a Emenda no 1 de 1969, tomo V/603),

não é dado à polícia analisar ou apreciar a conveniência da reunião - 'A polícia não pode intervir sem que haja perturbação da ordem. Simples inconvenientes não justificam a sua intervenção; tampouco a probabilidade de produzir o ato ou a reunião consequências disturbantes ou criminosas. Demais, o que lhe cabe resguardar é a ordem, $\underline{\mathbf{e}}$ não a defesa de determinados direitos privados, ou de governantes, porque tal missão é apenas da Justiça (grifei).

\section{Liberdade de reunião e direito à livre manifestação do pensamento: a proteção das minorias e a função contramajoritária da jurisdição constitucional no Estado Democrático de Direito}

O sentido de fundamentalidade de que se reveste essa liberdade pública permite afirmar que as minorias também titularizam, sem qualquer exclusão ou limitação, o direito de reunião, cujo exercício mostra-se essencial à propagação de suas ideias, de seus pleitos e de suas reivindicações, sendo completamente irrelevantes, para efeito de sua plena fruição, quaisquer resistências, por maiores que sejam, que a coletividade oponha às opiniões manifestadas pelos grupos minoritários, ainda que desagradáveis, atrevidas, insuportáveis, chocantes, audaciosas ou impopulares.

Daí a correta observação feita pelo Instituto Brasileiro de Ciências Criminais - IBCCRIM, neste processo, em primorosa sustentação de sua

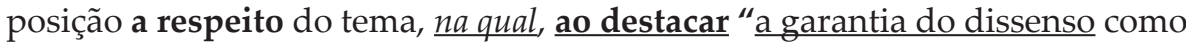


condição essencial à formação de uma opinião pública livre", enfatizou "으 caráter contramajoritário dos direitos fundamentais em causa":

A reivindicação por mudança, mediante manifestação que veicule uma ideia contrária à política de governo, não elide sua juridicidade. Ao contrário: a contraposição ao discurso majoritário situa-se, historicamente, no germe da liberdade da expressão enquanto comportamento juridicamente garantido. (...).

Os direitos fundamentais em causa, vocacionados à formação de uma opinião pública livre, socorrem fundamentalmente as minorias políticas, permitindo-lhes a legítima aspiração de tornarem-se, amanhã, maioria; esta é a lógica de um sistema democrático no qual o poder se submete à razão, e não a razão ao poder.

Decerto, inexistiria qualquer razão para que os direitos de liberdade de expressão, de reunião e de manifestação fossem alçados a tal condição caso seu âmbito normativo garantisse, exclusivamente, a exteriorização de concepções compartilhadas pela ampla maioria da sociedade ou pela política em vigor. Se para isso servissem, comporiam uma inimaginável categoria de "direitos desnecessários"; não seriam, pois, verdadeiros direitos.

A proibição do dissenso equivale a impor um "mandado de conformidade", condicionando a sociedade à informação oficial - uma espécie de "marketplace of ideas" (OLIVER WENDELL HOLMES) institucionalmente limitado. Ou, o que é ainda mais profundo: a imposição de um comportamento obsequioso produz, na sociedade, um pernicioso efeito dissuasório ("chilling effect"), culminando, progressivamente, com a aniquilação do próprio ato individual de reflexão (...).

A experiência histórica revela, pois, que o discurso antagônico não requer repressão, mas tolerância; se não fosse pela óbvia razão de que, despida de certo grau de tolerância, a convivência se tornaria socialmente insuportável, justificar-se-ia tal padrão de conduta pela sempre possível hipótese de que a "verdade" não esteja do lado da maioria.

Perceba-se, nessa linha de perspectiva: um candidato ou partido político que inclua em sua plataforma ou programa de governo a 
descriminalização de uma conduta delituosa está a fazer "apologia ao crime"?

No mesmo tom: seria ilegal uma manifestação pública tendente a arregimentar apoio à apresentação de um anteprojeto de lei de iniciativa popular com o objetivo de propor a descriminalização de determinada conduta? E a publicação de uma obra literária, individual ou coletiva, difundindo a mesma opinião? A propósito: a sustentação teórica do reducionismo penal - que, em termos radicais, designa-se "abolicionismo" - é prática criminosa? (grifei)

Essas reflexões do IBCCRIM, feitas em sua legítima condição de "amicus curiae", põem em evidência a função contramajoritária do Supremo Tribunal Federal no Estado democrático de direito, estimulando a análise da proteção das minorias na perspectiva de uma concepção material de democracia constitucional.

Na realidade, Senhor Presidente, esse tema acha-se intimamente associado ao presente debate constitucional, pois concerne ao relevantíssimo papel que ao Supremo Tribunal Federal incumbe desempenhar no plano da jurisdição das liberdades: o de órgão investido do poder e da responsabilidade institucional de proteger as minorias contra eventuais excessos da maioria ou, até mesmo, contra abusos perpetrados pelo próprio Poder Público e seus agentes.

Tal situação culmina por gerar um quadro de submissão de grupos minoritários à vontade hegemônica da maioria, o que compromete, gravemente, por reduzi-lo, o próprio coeficiente de legitimidade democrática das instituições do Estado, pois ninguém o ignora, o regime democrático não tolera nem admite a opressão da minoria por grupos majoritários.

Cabe enfatizar, presentes tais razões, que o Supremo Tribunal Federal, no desempenho da jurisdição constitucional, tem proferido, muitas vezes, decisões de caráter nitidamente contramajoritário, em clara demonstração de que os julgamentos desta Corte Suprema, quando assim proferidos, objetivam preservar, em gesto de fiel execução dos mandamentos constitucionais, $\underline{\mathbf{a}}$ intangibilidade de direitos, interesses e valores que identificam os grupos minoritários expostos a situações de vulnerabilidade jurídica, social, econômica ou política e que, por efeito de tal condição, tornam-se objeto de intolerância, de perseguição, de discriminação, de injusta exclusão, de repressão $\underline{\mathbf{e}}$ de abuso contra os seus direitos.

$\mathrm{Na}$ realidade, o tema da preservação e do reconhecimento dos direitos das minorias deve compor, por tratar-se de questão impregnada do mais alto relevo, a agenda desta Corte Suprema, incumbida, por efeito de sua 
destinação institucional, de velar pela supremacia da Constituição e de zelar pelo respeito aos direitos, inclusive de grupos minoritários, que encontram fundamento legitimador no próprio estatuto constitucional.

Com efeito, a necessidade de assegurar-se, em nosso sistema jurídico, proteção às minorias e aos grupos vulneráveis qualifica-se, na verdade, como fundamento imprescindível à plena legitimação material do Estado Democrático de Direito, havendo merecido tutela efetiva, por parte desta Suprema Corte, quando grupos majoritários, por exemplo, atuando no âmbito do Congresso Nacional, ensaiaram medidas arbitrárias destinadas a frustrar o exercício, por organizações minoritárias, de direitos assegurados pela ordem constitucional (MS 24.831/DF, Rel. Min. CELSO DE MELLO - $\underline{\text { MS }}$ 24.849/DF, Rel. Min.

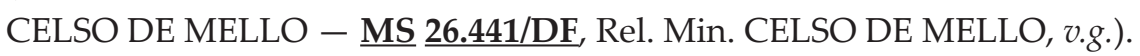

Lapidar, sob a perspectiva de uma concepção material de democracia constitucional, a lúcida advertência do saudoso e eminente Professor GERALDO ATALIBA (Judiciário e minorias, Revista de Informação Legislativa, vol. 96/194):

A Constituição verdadeiramente democrática há de garantir todos os direitos das minorias e impedir toda prepotência, todo arbítrio, toda opressão contra elas. Mais que isso - por mecanismos que assegurem representação proporcional -, deve atribuir um relevante papel institucional às correntes minoritárias mais expressivas.

Na democracia, governa a maioria, mas - em virtude do postulado constitucional fundamental da igualdade de todos os cidadãos - ao fazê-lo, não pode oprimir a minoria. Esta exerce também função política importante, decisiva mesmo: a de oposição institucional, a que cabe relevante papel no funcionamento das instituições republicanas.

O principal papel da oposição é o de formular propostas alternativas às ideias e ações do governo da maioria que o sustenta. Correlatamente, critica, fiscaliza, aponta falhas e censura a maioria, propondo-se, à opinião pública, como alternativa. Se a maioria governa, entretanto, não é dona do poder, mas age sob os princípios da relação de administração.

Daí a necessidade de garantias amplas, no próprio texto constitucional, de existência, sobrevivência, liberdade de ação e influência da minoria, para que se tenha verdadeira república. 
Pela proteção e resguardo das minorias e sua necessária participação no processo político, a república faz da oposição instrumento institucional de governo.

É imperioso que a Constituição não só garanta a minoria (a oposição), como ainda lhe reconheça direitos e até funções.

Se a maioria souber que - por obstáculo constitucional - não pode prevalecer-se da força, nem ser arbitrária nem prepotente, mas deve respeitar a minoria, então os compromissos passam a ser meios de convivência política. (...). (grifei)

Também o eminente e saudoso Professor PINTO FERREIRA (Princípios Gerais do Direito Constitucional Moderno, tomo I/195-196, item n. 8, 5a ed., 1971, RT) demonstra igual percepção do tema ao enfatizar - com fundamento em irrepreensíveis considerações de ordem doutrinária - que a essência democrática de qualquer regime de governo apoia-se na existência de uma imprescindivel harmonia entre a "Majority rule" e os "Minority rights":

A verdadeira ideia da democracia corresponde, em geral, a uma síntese dialética dos princípios da liberdade, igualdade e dominação da maioria, com a correlativa proteção às minorias políticas, sem o que não se compreende a verdadeira democracia constitucional.

A dominação majoritária em si, como o centro de gravidade da democracia, exige esse respeito às minorias políticas vencidas nas eleições. O princípio majoritário é o polo positivo da democracia, e encontra a sua antítese no princípio minoritário, que constitui o seu polo negativo, ambos estritamente indispensáveis na elucidação do conceito da autêntica democracia.

O princípio democrático não é, pois, a tirania do número, nem a ditadura da opinião pública, nem tampouco a opressão das minorias, o que seria o mais rude dos despotismos. A maioria do povo pode decidir o seu próprio destino, mas com o devido respeito aos direitos das minorias políticas, acatando nas suas decisões os princípios invioláveis da liberdade e da igualdade, sob pena de se aniquilar a própria democracia. 
A livre deliberação da maioria não é suficiente para determinar a natureza da democracia. STUART MILL já reconhecia essa impossibilidade, ainda no século transato: "Se toda a humanidade, menos um, fosse de uma opinião, não estaria a humanidade mais justificada em reduzir ao silêncio tal pessoa, do que esta, se tivesse força, em fazer calar o mundo inteiro". Em termos não menos positivos, esclarece o sábio inglês, nas suas "Considerations on Representative Government", quando fala da verdadeira e da falsa democracia ("of true and false Democracy"): "A falsa democracia é só representação da maioria, a verdadeira é representação de todos, inclusive das minorias. A sua peculiar e verdadeira essência há de ser, destarte, um compromisso constante entre maioria e minoria". (grifei)

\section{Grupos majoritários não podem submeter, à hegemonia de sua vontade, a eficácia de direitos fundamentais, que se revestem de nítido caráter contramajoritário, especialmente se analisado esse tema na perspectiva de uma concepção material de democracia constitucional}

$\underline{\text { O Estado de Direito }}$ concebido e estruturado em bases democráticas, mais do que simples figura conceitual ou mera proposição doutrinária, reflete, em nosso sistema jurídico, uma realidade constitucional densa de significação e plena de potencialidade concretizadora dos direitos e das liberdades públicas.

A opção do legislador constituinte pela concepção democrática do Estado de Direito não pode esgotar-se numa simples proclamação retórica. $\underline{\text { A opção }}$ pelo Estado democrático de direito, por isso mesmo, há de ter consequências efetivas no plano de nossa organização política, na esfera das relações institucionais entre os poderes da República e no âmbito da formulação de uma teoria das liberdades públicas e do próprio regime democrático. Em uma palavra: ninguém se sobrepõe, nem mesmo os grupos majoritários, aos princípios superiores consagrados pela Constituição da República, cujo texto confere, aos direitos fundamentais, um nítido caráter contramajoritário.

É evidente que o princípio majoritário desempenha importante papel no processo decisório que se desenvolve no âmbito das instâncias governamentais, mas não pode legitimar, na perspectiva de uma concepção material de democracia constitucional, a supressão, a frustração e a aniquilação de direitos 
fundamentais, como o livre exercício do direito de reunião e da liberdade de expressão (e, também, o do direito de petição), sob pena de descaracterização da própria essência que qualifica o Estado democrático de direito.

Desse modo, e para que o regime democrático ña se reduza a uma categoria político-jurídica meramente conceitual ou simplesmente formal, torna-se necessário assegurar, às minorias, notadamente em sede jurisdicional, quando tal se impuser, a plenitude de meios que lhes permitam exercer, de modo efetivo, os direitos fundamentais que a todos, sem distinção, são assegurados.

Isso significa, portanto, numa perspectiva pluralística, em tudo compatível com os fundamentos estruturantes da própria ordem democrática (CF, art. 1으, V), que se impõe a organização de um sistema de efetiva proteção, especialmente no plano da jurisdição, aos direitos, liberdades e garantias fundamentais em favor das minorias, quaisquer que sejam, para que tais prerrogativas essenciais não se convertam em fórmula destituída de significação, o que subtrairia consoante adverte a doutrina (SÉRGIO SÉRVULO DA CUNHA, Fundamentos de Direito Constitucional, p. 161/162, item n. 602.73, 2004, Saraiva) - $\underline{\text { o }}$ necessário coeficiente de legitimidade jurídico-democrática ao regime político vigente em nosso País.

Daí a inteira procedência da observação feita pela eminente Dra. DEBORAH MACEDO DUPRAT DE BRITTO PEREIRA, na petição inicial que subscreveu, com brilhante fundamentação, na condição de ProcuradoraGeral da República:

Uma idea fundamental, subjacente à liberdade de expressão, é a de que o Estado não pode decidir, pelos indivíduos, o que cada um pode ou não pode ouvir. Como ressaltou Ronald Dworkin, "o Estado insulta os seus cidadãos e nega a eles responsabilidade moral, quando decreta que não se pode confiar neles para ouvir opiniões que possam persuadi-los a adotar convicções perigosas ou ofensivas".

Daí por que o fato de uma ideia ser considerada errada ou mesmo perniciosa pelas autoridades públicas de plantão não é fundamento bastante para justificar que a sua veiculação seja proibida. A liberdade de expressão não protege apenas as ideias aceitas pela maioria, mas também - e sobretudo aquelas tidas como absurdas e até perigosas. Trata-se, em suma, de um instituto contramajoritário que garante o direito daqueles que defendem posições minoritárias, que desagradam ao governo ou contrariam os valores hegemônicos da sociedade, de expressarem suas visões alternativas. (grifei) 


\section{As plurissignificações do art. 287 do Código Penal: necessidade de interpretar esse preceito legal em harmonia com as liberdades fundamentais de reunião, de expressão e de petição}

Vê-se, portanto, que o litígio constitucional instaurado na presente causa é motivado por abordagens hermenêuticas diversas em torno do art. 287 do Código Penal, precisamente em face do conteúdo polissêmico desse preceito legal, o que é atestado pela existência de provimentos judiciais conflitantes a propósito da questão, eis que há decisões que reconhecem que o art. 287 do Código Penal impede a realização de qualquer marcha ou passeata que objetive propor a discussão pública sobre a legalização do uso de drogas ou de substâncias correlatas, frustrando-se, assim, o exercício de liberdades públicas fundamentais, cuja prática tem sido duramente atingida e gravemente obstada por notórias medidas repressivas adotadas pelo Estado e seus agentes em função de pronunciamentos do Poder Judiciário que consideram apologia de fato criminoso as condutas daqueles que organizam, promovem e/ou participam de movimentos como o da "Marcha da Maconha".

De outro lado, registram-se decisões que, proferidas em sentido diametralmente oposto, buscam compatibilizar o art. 287 do Código Penal com o texto da Constituição, interpretando-o de forma a nãa inviabilizar o exercício da liberdade de reunião e a prática dos direitos de petição e de livre manifestação do pensamento.

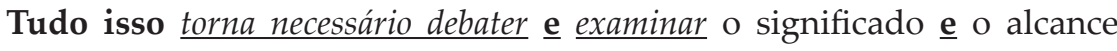
de determinadas liberdades fundamentais - a liberdade de reunião, a liberdade de manifestação do pensamento e, também, o direito de petição - cujo exercício tem sido inviabilizado, pelo Poder Público, sob a equivocada interpretação de que manifestações públicas (e pacíficas), como a "Marcha da Maconha", configurariam a prática do ilícito tipificado no art. 287 do Código Penal, que define, como entidade delituosa, a "apologia de fato criminoso", não obstante destinadas, tais manifestações, a veicular ideias, a transmitir opiniões, a formular protestos e a expor reivindicações (direito de petição), com a finalidade de sensibilizar a comunidade e as autoridades governamentais, notadamente os seus legisladores, para a delicada questão da descriminalização ("abolitio criminis") do uso das drogas ou de qualquer substância entorpecente específica. 
Extremamente precisa, a esse propósito, a referência que o IBCCRIM faz, em sua formal intervenção nesta causa, à delimitação material do objeto da presente demanda constitucional, especialmente no ponto em que assim se manifesta:

O objeto desta ADPF não se confunde com o objeto das reuniões ou manifestações que, sob contínua ameaça de repressão do Poder Público, justificaram a presente medida. (...).

A temática jurídica submetida à apreciação desse Supremo Tribunal Federal situa-se em domínios normativos superiores, de feição constitucional; mais precisamente, no âmbito das liberdades individuais: estão em pauta os direitos fundamentais de reunião e de manifestação, enquanto projeções da liberdade de expressão, em cujo núcleo essencial incluem-se as faculdades de protesto e de reivindicação, pressupostos de uma sociedade livre, aberta e pluralista.

Nessa perspectiva, as manifestações que, sob ilegítima expansão normativa dos limites do art. 287 do Código Penal, vêm sofrendo censura estatal poderiam ter por conteúdo matérias reivindicatórias as mais diversas ('v.g.', a descriminalização do aborto, da eutanásia ou de qualquer outra conduta incriminada sobre a qual a sociedade esteja dividida); ainda assim, o objeto da ADPF persistiria o mesmo.

É preciso, outrossim, que fique claro: a proteção judicial ora postulada não contempla - e nem poderia fazê-lo - a criação de um espaço público circunstancialmente imune à ação fiscalizatória ordinária do Estado; menos ainda se propugna que, no exercício das liberdades ora reivindicadas, manifestantes possam incorrer em ilicitude de qualquer espécie, como, por exemplo, consumir drogas. O espectro de liberdade que se objetiva ver assegurado é aquele inerente - portanto, adequado e necessário - aos direitos fundamentais implicados, sem que daí decorra implícita permissão à prática de conduta que se possa traduzir em violação às normas integradoras do Direito em vigor. (grifei)

É por isso que a douta Procuradoria-Geral da República, após enfatizar, com apoio em magistério doutrinário, que a liberdade de reunião acha-se submetida a um limite implícito, que é a sua finalidade lícita corretamente observa: 
(...) é perfeitamente lícita a defesa pública da legalização das drogas, na perspectiva do legítimo exercício da liberdade de expressão.

Evidentemente, seja ilícita uma reunião em que as pessoas se encontrassem para consumir drogas ilegais ou para instigar terceiros a usálas. Não é este o caso de reunião voltada à crítica da legalização penal e de políticas públicas em vigor, em que se defenda a legalização das drogas em geral, ou de alguma substância entorpecente em particular. (grifei)

O direito de reunião, Senhor Presidente, também surge como verdadeira precondição necessária à ativa participação dos cidadãos no processo político e no de tomada de decisões, notadamente agora em que o sistema constitucional brasileiro confere legitimidade ativa aos cidadãos para a instauração, por iniciativa popular do processo legislativo, o que habilita o eleitorado a propor, ao Congresso Nacional, nos termos do art. 14, III, e do art. 61 , § 2을 da Constituição, projetos de lei objetivando, até mesmo, a própria "abolitio criminis" referente a qualquer conduta hoje penalmente punível.

Legítimos, pois, sob perspectiva estritamente constitucional, a assembleia, a reunião, a passeata, a marcha ou qualquer outro encontro realizados, em espaços públicos, com o objetivo de obter apoio para eventual proposta de legalização do uso de drogas, de criticar o modelo penal de repressão e punição ao uso de substâncias entorpecentes, de propor alterações na legislação penal pertinente, de formular sugestões concernentes ao sistema nacional de políticas públicas sobre drogas, de promover atos de proselitismo em favor das posições sustentadas pelos manifestantes e participantes da reunião, ou, finalmente, de exercer o direito de petição quanto ao próprio objeto motivador da assembleia, passeata ou encontro.

\section{Vinculação de caráter instrumental entre a liberdade de reunião e o direito de petição}

Mostra-se relevante salientar, agora, Senhor Presidente, que igualmente existe uma clara relação de instrumentalidade entre a liberdade de reunião e o direito de petição, que também se qualifica como expressiva prerrogativa de natureza constitucional e de caráter político-jurídico, inerente ao próprio exercício da cidadania. 
Como sabemos, a declaração constitucional de direitos, inscrita no texto de nossa Lei Fundamental, assegura, a todos, o direito de petição aos poderes públicos, consagrando, em favor das pessoas em geral, uma faculdade que tem sido reconhecida ao longo do constitucionalismo brasileiro, desde a Carta Política do Império do Brasil (art. 179, n. 30), transitando, sem qualquer exceção por todas as Constituições republicanas, até o vigente ordenamento constitucional $(\underline{\mathrm{CF} / 88}$ art. 5, inciso XXXIV, " $a$ "), sempre atribuindo, aos cidadãos $\underline{\mathbf{e}}$ à generalidade das pessoas, a prerrogativa de apresentar, aos órgãos competentes do Estado, queixas, reclamações e denúncias de abusos, além de propiciar-lhes a possibilidade de oferecer representação propondo a adoção de medidas que materializem a sua posição e o seu pensamento a propósito de certa matéria ou tema específico, como sucede, $p$. ex., com os que, congregando-se, pacificamente, em praça pública, propõem ao Poder Legislativo (destinatário precípuo da manifestação popular) a adoção de medidas descriminalizadoras do uso e consumo de drogas em geral e de determinada substância entorpecente em particular.

Vale ter presente, neste ponto, a observação que PONTES DE MIRANDA (Comentários à Constituição de 1967 com a Emenda no 1 de 1969, tomo V/630, item n. 3, 2aㅡ. ed./2 tir., 1974, RT) faz sobre o direito de petição, que surgiu, historicamente, no contexto da Revolução Gloriosa (1688), com a Declaração de Direitos britânica de 1689 ("Bill of Rights"), que assegurava (como ainda assegura), aos súditos, o direito de se dirigir ao monarca reinante (e ao Parlamento), propondo-lhes a adoção de medidas ou de providências indicadas em pleito individual ou coletivo:

(...) é o direito público subjetivo de petição, com as pretensões respectivas, qualquer que seja o interêsse ou direito-base que invoque o peticionário, e independe de qualquer prova de interêsse próprio. Os podêres públicos são apenas adstritos a proferir despacho, ou designar comissão que estude as reclamações feitas. Porém, o Poder Legislativo não pode deixar de designar comissão "ad hoc", ou permanente, que dê parecer, sujeito, ou não, a plenário. $\mathbf{O}$ arquivamento, sem qualquer resposta, constitui violação do enunciado da Constituição. A praxe é dar parecer a Comissão de Petições e enviá-lo, depois, com a petição, às outras Comissões, a que, pela matéria, interesse. Formou-se a relação jurídica processual, especialíssima, e o Estado tem o dever de prestação, em solução favorável ou não (grifei). 


\section{VII. "A Marcha da Maconha": expressão concreta do exercício legítimo, porque fundado na Constituição da República, das liberdades fundamentais de reunião, de manifestação do pensamento e de petição}

É importante destacar, de outro lado, Senhor Presidente, que, ao contrário do que algumas mentalidades repressivas sugerem, a denominada "Marcha da Maconha", longe de pretender estimular o consumo de drogas ilícitas, busca, na realidade, expor, de maneira organizada e pacífica, apoiada no princípio constitucional do pluralismo político (fundamento estruturante do Estado democrático de direito), as ideias, a visão, as concepções, as críticas e as propostas daqueles que participam, como organizadores ou como manifestantes, desse evento social, amparados pelo exercício concreto dos direitos fundamentais de reunião, de livre manifestação do pensamento e de petição.

Nesse contexto, a questionada (e tão reprimida) "Macha da Maconha" é bem a evidência de como se interconexionam as liberdades constitucionais de reunião (direito-meio) e de manifestação do pensamento (direito-fim ou, na expressão de Pedro Lessa, "direito-escopo"), além do direito de petição, todos eles igualmente merecedores do amparo do Estado, cujas autoridades - longe de transgredirem tais prerrogativas fundamentais - deveriam protegê-las, revelando tolerância e respeito por aqueles que, congregando-se em espaços públicos, pacificamente, sem armas, apenas pretendem, Senhor Presidente, valendo-se, legitimamente, do direito à livre expressão de suas ideias e opiniões, transmitir, mediante concreto exercício do direito de petição, mensagem de abolicionismo penal quanto à vigente incriminação do uso de drogas ilícitas.

Cabe rememorar, bem por isso, as observações feitas pelo ilustre Advogado e Professor SALO DE CARVALHO (A Política Criminal de Drogas no Brasil - Estudo Criminológico e Dogmático da Lei 11.343/06, p. 258/261, item n. 12.10, 5a ed., 2010, Lumen Juris), que, em precisa exposição, indicou as finalidades legítimas perseguidas pelos que participam, sob o amparo das liberdades fundamentais de reunião e de manifestação do pensamento, dos encontros e eventos promovidos pelos organizadores de referida manifestação pública:

Realizada anualmente a partir de 1999 em várias cidades do planeta, a Marcha da Maconha é caracterizada por série de eventos de apoio às políticas antiproibicionistas e de redução de danos. Em festividades realizadas no primeiro sábado do mês de maio, considerado o Dia 
Mundial pela Descriminalização da "Cannabis", são organizados encontros, passeatas, fóruns de debates, festas, concertos e festivais. Idealizada e coordenada por organizações civis e públicas não governamentais, a Marcha objetiva realização de manifestações pacíficas, performances culturais e atos de livre expressão para informação e discussão de políticas públicas que envolvem a (des)criminalização da "cannabis".

Segundo os organizadores, a ideia principal do evento é a promoção de debate sério sobre as políticas públicas que envolvem as drogas, sendo os participantes incentivados a não fazer uso de qualquer tipo de droga, lícita ou ilícita, especialmente o álcool, durante as manifestações. Constitui-se tanto como movimento social espontâneo, reivindicatório e de livre exposição do pensamento.

No Brasil, na última década, inúmeros coletivos aderiram à Marcha, seguindo o movimento global de manifestação contrária às políticas proibicionistas. A organização nacional, ao longo dos anos, publicizou amplamente a intenção de debater o tema da criminalização e os efeitos produzidos pela atual política criminal de drogas no Brasil e na América Latina. No ambiente virtual mantido pelos grupos e instituições que representam o Movimento, encontra-se a seguinte exposição de motivos:

Os objetivos principais do Coletivo são: Criar espaços onde indivíduos e instituições interessadas em debater a questão possam se articular e dialogar; Estimular reformas nas Leis e Políticas Públicas sobre a maconha e seus diversos usos; Ajudar a criar contextos sociais, políticos e culturais onde todos os cidadãos brasileiros possam se manifestar de forma livre e democrática a respeito das políticas e leis sobre drogas; Exigir formas de elaboração e aplicação dessas políticas e leis que sejam mais transparentes, justas, eficazes e pragmáticas, respeitando a cidadania e os Direitos Humanos.

O Coletivo Marcha da Maconha Brasil reafirma que suas atividades não têm a intenção de fazer apologia à maconha ou ao seu uso, nem incentivar qualquer tipo de atividade criminosa. As atividades do Coletivo respeitam não só o direito à livre manifestação de ideias e opiniões, mas também os limites legais desse e de outros direitos. 
Na Carta de Princípios da Marcha da Maconha no Brasil, os integrantes expressam os objetivos da manifestação:

A Marcha da Maconha Brasil é um movimento social, cultural e político, cujo objetivo é levantar a proibição hoje vigente em nosso país em relação ao plantio e consumo da "cannabis", tanto para fins medicinais como recreativos. Também é nosso entendimento que o potencial econômico dos produtos feitos de cânhamo deve ser explorado especialmente quando isto for adequado sob o ponto de vista ambiental.

A Marcha da Maconha Brasil não é um movimento de apologia ou incentivo ao uso de qualquer droga, o que inclui a "cannabis". No entanto, partilhamos do entendimento de que a política proibicionista radical hoje vigente no Brasil e na esmagadora maioria dos países do mundo é um completo fracasso, que cobra um alto preço em vidas humanas e recursos públicos desperdiçados.

A Marcha da Maconha Brasil não tem posição sobre a legalização de qualquer outra substância além da "cannabis", a favor ou contra. $\mathrm{O}$ nosso objetivo limita-se a promover o debate sobre a planta em questão e demonstrar para a sociedade brasileira a inadequação de sua proibição.

A Marcha da Maconha Brasil tem como objetivo agregar todos aqueles que comunguem dessa visão, usuários da erva ou não, que desejem colaborar de alguma forma para que a proibição seja derrubada. Os que estão presos pelo simples fato de plantar a "cannabis" para uso pessoal são considerados presos políticos, assim como todos aqueles que estão atrás das grades sem ter cometido violência nenhuma contra ninguém, por delitos relacionados a esse vegetal que o conservadorismo obscurantista teima em banir.

Para atingir os seus objetivos, a Marcha da Maconha Brasil atuará estritamente dentro da Constituição e das leis. Não abrimos mão da liberdade de expressão, mas também não promovemos a desobediência a nenhuma lei. Entretanto, reconhecemos que, se a sociedade tem o dever de cumprir a lei elaborada e aprovada por seus representantes eleitos, os legisladores devem exercer a sua função em sintonia com a evolução da sociedade. 
Uma vez por ano, simultaneamente com o movimento internacional "Global Marijuana March", a Marcha da Maconha Brasil organizará e convocará manifestações públicas pela legalização da "cannabis". Além disso, também poderão ser organizadas outras atividades, tais como seminários, conferências e debates, inclusive em colaboração com outros grupos e movimentos, nacionais e estrangeiros.

Percebe-se, da leitura do material de divulgação, que a finalidade do movimento é problematizar a política criminal proibicionista. Trata-se, portanto, de movimento social espontâneo que reivindica a possibilidade, através da livre manifestação do pensamento, da discussão democrática do modelo proibicionista e dos efeitos que produziu em termos de incremento da violência. Ademais, o evento Marcha da Maconha possui, nitidamente, caráter cultural e artístico, em face da programação de atividades musicais, teatrais e performáticas, além da criação de espaço de debate com palestras, seminários e exibições de documentários relacionados às políticas públicas ligadas às drogas, lícitas e ilícitas.

Em razão dos dados apresentados, incabível entender as condutas como apologia de fato criminoso, não apenas porque houve a descriminalização do tipo específico existente na revogada Lei 6.368/76, mas porque sequer há possibilidade de subsunção ao art. 287 do Código Penal.

Note-se que o bem jurídico tutelado pelo tipo penal do art. 287 do Código Penal é a paz pública. Assim, a conduta, para constituir materialmente delito, deve, necessariamente, gerar, no seio social, perturbação. Segundo a doutrina, "fazer apologia significa defender, justificar, elogiar, enaltecer, defender. Trata-se da conduta daquele que, publicamente, enaltece o fato criminoso ou o autor do crime".

No caso da Marcha da Maconha, do que se pode perceber, não há qualquer espécie de enaltecimento, defesa ou justificativa do porte para consumo ou do tráfico de drogas ilícitas, figuras tipificadas nos art. 28 e 33 da Lei 11.343/06. Ao contrário, resta evidente a tentativa de pautar importante (e necessário) debate acerca das políticas públicas e dos efeitos do proibicionismo. (grifei) 


\section{A liberdade de manifestação do pensamento: um dos mais preciosos privilégios dos cidadãos}

Tenho sempre enfatizado nesta Corte, Senhor Presidente, que nada se revela mais nocivo e mais perigoso do que a pretensão do Estado de reprimir a liberdade de expressão, mesmo que se objetive, com apoio nesse direito fundamental, expor ideias ou formular propostas que a maioria da coletividade repudie, pois, nesse tema, guardo a convicção de que o pensamento há de ser livre, sempre livre, permanentemente livre, essencialmente livre.

Torna-se extremamente importante reconhecer, desde logo, que, sob a égide da vigente Constituição da República, intensificou-se, em face de seu inquestionável sentido de fundamentalidade, a liberdade de manifestação do pensamento.

Ninguém desconhece que, no contexto de uma sociedade fundada em bases democráticas, mostra-se intolerável a repressão estatal ao pensamento.

Não custa insistir neste ponto, na asserção de que a Constituição da República revelou hostilidade extrema a quaisquer práticas estatais tendentes a restringir ou a reprimir o legítimo exercício da liberdade de expressão e de comunicação de ideias e de pensamento.

Essa repulsa constitucional bem traduziu o compromisso da Assembleia Nacional Constituinte de dar expansão às liberdades do pensamento. Estas são expressivas prerrogativas constitucionais cujo integral e efetivo respeito, pelo Estado, qualifica-se como pressuposto essencial e necessário à prática do regime democrático. A livre expressão e manifestação de ideias, pensamentos e convicções não pode e não deve ser impedida pelo Poder Público nem submetida a ilícitas interferências do Estado.

Não deixo de reconhecer, Senhor Presidente, que os valores que informam a ordem democrática, dando-lhe o indispensável suporte axiológico, revelam-se conflitantes com toda e qualquer pretensão estatal que vise a nulificar ou a coarctar a hegemonia essencial de que se revestem, em nosso sistema constitucional, as liberdades do pensamento.

$\mathrm{O}$ regime constitucional vigente no Brasil privilegia, de modo particularmente expressivo, o quadro em que se desenvolvem as liberdades do pensamento. Esta é uma realidade normativa, política e jurídica que não pode ser desconsiderada pelo Supremo Tribunal Federal.

A liberdade de expressão representa, dentro desse contexto, uma projeção significativa do direito, que a todos assiste, de manifestar, sem qualquer possibilidade de intervenção estatal "a priori", as suas convicções, expondo 
as suas ideias $\underline{\text { e fazendo }}$ veicular as suas mensagens doutrinárias, ainda que impopulares, contrárias ao pensamento dominante ou representativas de concepções peculiares a grupos minoritários.

É preciso reconhecer que a vedação dos comportamentos estatais que afetam tão gravemente a livre expressão e comunicação de ideias significou um notável avanço nas relações entre a sociedade civil e o Estado. Nenhum diktat, emanado do Estado, pode ser aceito ou tolerado, na medida em que venha a comprometer o pleno exercício da liberdade de expressão.

A Constituição, ao subtrair da interferência do Poder Público, o processo de comunicação e de livre expressão das ideias, ainda que estas sejam rejeitadas por grupos majoritários, mostrou-se atenta à grave advertência de que o Estado não pode dispor de poder algum sobre a palavra, sobre as ideias e sobre os modos de sua manifestação.

Impende advertir, bem por isso, notadamente quando os agentes do Poder, atuando de forma incompatível com a Constituição, buscam promover a repressão à liberdade de expressão, vedando o exercício do direito de reunião e, assim, frustrando, de modo injusto e arbitrário, a possibilidade de livre exposição de opiniões, que o Estado não dispõe de poder algum sobre a palavra, sobre as ideias, sobre o pensamento e sobre as convicções manifestadas pelos cidadãos.

Essa garantia básica da liberdade de expressão do pensamento, como precedentemente assinalado, representa, em seu próprio e essencial significado, um dos fundamentos em que repousa a ordem democrática. Nenhuma autoridade pode prescrever o que será ortodoxo em política, ou em outras questões que envolvam temas de natureza filosófica, jurídica, social, ideológica ou confessional, nem estabelecer padrões de conduta cuja observância implique restrição à própria manifestação do pensamento. Isso, porque "o direito de pensar, falar e escrever livremente, sem censura, sem restrições ou sem interferência governamental" representa, conforme adverte HUGO LAFAYETTE BLACK, que integrou a Suprema Corte dos Estados Unidos da América (1937-1971), “o mais precioso privilégio dos cidadãos...” (Crença na Constituição, p. 63, 1970, Forense).

É certo que o direito à livre expressão do pensamento não se reveste de caráter absoluto, pois sofre limitações de natureza ética e de caráter jurídico.

É por tal razão que a incitação ao ódio público contra qualquer pessoa, povo ou grupo social não está protegida pela cláusula constitucional que assegura a liberdade de expressão.

Cabe relembrar, neste ponto, a própria Convenção Americana sobre Direitos Humanos (Pacto de São José da Costa Rica), cujo Art. 13, § 5o, 
exclui do âmbito de proteção da liberdade de manifestação do pensamento "toda propaganda a favor da guerra, bem como toda apologia ao ódio nacional, racial ou religioso que constitua incitação à discriminação, à hostilidade, ao crime ou à violência".

Tenho por irrecusável, Senhor Presidente, que a liberdade de manifestação do pensamento, impregnada de essencial transitividade, destina-se a proteger qualquer pessoa cujas opiniões possam, até mesmo, conflitar com as concepções prevalecentes, em determinado momento histórico, no meio social, impedindo que incida, sobre ela, por conta e efeito de suas convicções, qualquer tipo de restrição de índole política ou de natureza jurídica, pois todos hão de ser livres para exprimir ideias, ainda que estas possam insurgir-se ou revelar-se em desconformidade frontal com a linha de pensamento dominante no âmbito da coletividade.

Vale relembrar, no ponto, o magistério, sempre valioso, de CELSO DELMANTO, ROBERTO DELMANTO, ROBERTO DELMANTO JUNIOR e FABIO M. DE ALMEIDA DELMANTO (Código Penal Comentado, p. 820, 8a ed., 2010, Saraiva), cujos comentários, por extremamente relevantes, reproduzo a seguir, notadamente porque esses eminentes autores corretamente procedem a uma interpretação do art. 287 do Código Penal em conformidade com a Constituição e com o que ela estabelece em tema de liberdades fundamentais:

Liberdades públicas: Pode ocorrer que a conduta do agente esteja amparada por garantias constitucionais, como ocorre com as da liberdade de manifestação do pensamento (CR, art. 5ํ, IV) e da livre expressão da atividade intelectual, artística, científica e de comunicação, independente de censura ou licença (inciso IX), havendo um conflito aparente de normas com a proibição prevista no crime deste art. 287. O que o Direito Penal pune, evidentemente, são os "abusos" no exercício dessas liberdades. Dependendo do caso, não haverá antijuridicidade ou ilicitude na conduta daquele que, por exemplo, propugna pela descriminalização do aborto, do porte de droga para uso próprio e da eutanásia. Isto porque, defender a descriminalização de certas condutas previstas em lei como crime, não é fazer apologia de fato criminoso ou de autor de crime. Igualmente, não configura o crime deste art. 287 a conduta daquele que usa camiseta com a estampa da folha da maconha, por ser inócua a caracterizar o crime e por estar abrangida na garantia constitucional da liberdade de manifestação do pensamento. (grifei) 


\section{A proposta de legalização do uso de drogas, inclusive da "Cannabis Sativa Linnaeus", ainda que defendida fora de ambientes acadêmicos, em espaços públicos ou privados, é amparada pelas liberdades constitucionais de reunião, de manifestação do pensamento e de petição}

Desejo salientar, neste ponto, Senhor Presidente, já me aproximando do encerramento deste voto, que a mera proposta de descriminalização de determinado ilícito penal não se confunde com o ato de incitação à prática do delito, nem com o de apologia de fato criminoso, eis que o debate sobre a abolição penal de determinadas condutas puníveis pode (e deve) ser realizado de forma racional, com respeito entre interlocutores, ainda que a ideia, para a maioria, possa ser eventualmente considerada estranha, extravagante, inaceitável ou, até mesmo, perigosa.

É relevante destacar que já se registraram, no ordenamento positivo brasileiro, diversos casos de "abolitio criminis", cabendo mencionar, dentre eles, em tempos mais recentes, a descaracterização típica do adultério (CP, art. 240), da sedução (CP, art. 217) e do rapto consensual (CP, art. 220).

Impõe-se rememorar, aqui, fato historicamente expressivo, além de impregnado de inequívoco significado jurídico: refiro-me a comportamento que era punido, como delito, pelo Código Penal de 1890, que foi o primeiro estatuto penal da República, cujo art. 402 definia, como ato passível de repressão penal (pena de 2 a 6 meses de prisão celular), a conduta consistente em "Fazer, nas ruas e praças públicas, exercícios de agilidade e destreza corporal conhecidos pela denominação de capoeiragem (...)".

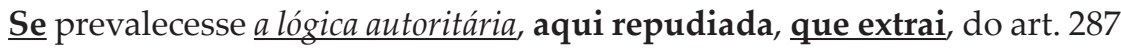
do vigente Código Penal, em interpretação absolutamente incompatível com o texto da Constituição, a existência do delito de apologia de fato criminoso, nele enquadrando o comportamento dos que sustentam, publicamente, a descriminalização de determinado ato punível, estar-se-ia reconhecendo, em tal contexto, a possibilidade de incriminação dos que pugnaram pela legalização da prática da capoeiragem ou que, nesta, vislumbraram manifestação de caráter folclórico ou de índole cultural, como o fez, em 1932, em declaração pública, Gustavo Capanema, então Ministro da Educação e Saúde do Governo Provisório de Getúlio Vargas, que proclamou, textualmente, que "A capoeira é o esporte nacional brasileiro", o que permitiu retirar, nos anos subsequentes, das páginas da repressão criminal, a atividade de capoeira, pois, como se sabe, 
a capoeira, hoje, acha-se vinculada à Confederação Brasileira de Capoeira, entidade reconhecida pelo próprio Comitê Olímpico Brasileiro, sendo digno de nota, ainda, o fato de que a "Roda de Capoeira" foi qualificada, pelo Instituto do Patrimônio Histórico e Artístico Nacional (IPHAN), em 21/10/2008, como prática integrante do Patrimônio Cultural do Brasil.

Enfatize-se, Senhor Presidente, que jamais se cogitou, quanto aos autores de tais propostas - $\underline{\text { não importando }}$ se formuladas na esfera da sociedade civil ou no âmbito do Congresso Nacional (e que objetivavam a descriminalização, dentre outros, dos delitos de capoeiragem, de adultério, de sedução e de rapto consensual) - , que tivessem eles cometido o delito tipificado no art. 287 do Código Penal, o que, se ocorrido, constituiria um rematado absurdo...

Há que se reconhecer, ainda, no que se refere à pretendida descriminalização do uso de drogas, inclusive da maconha, que essa tese é sustentada, publicamente, por diversas entidades, tais como a Comissão Latino-Americana sobre Drogas e Democracia, presidida pelo ex-Presidente da República Fernando Henrique Cardoso, que, em artigo publicado no "Valor Econômico" ("A Guerra contra as Drogas", em 18/1/2011), e após observar que a guerra contra as drogas "é uma guerra perdida", impondo-se, por isso mesmo, uma ruptura de paradigma na análise e enfrentamento dessa questão, teceu as seguintes observações:

A guerra contra as drogas é uma guerra perdida e 2011 é o momento para afastar-se da abordagem punitiva e buscar um novo conjunto de políticas baseado na saúde pública, direitos humanos e bom senso. Essas foram as principais conclusões da Comissão Latino-Americana sobre Drogas e Democracia que organizei, ao lado dos ex-presidentes Ernesto Zedillo, do México, e César Gaviria, da Colômbia.

Envolvemo-nos no assunto por um motivo persuasivo: a violência e a corrupção associadas ao tráfico de drogas representam uma grande ameaça à democracia em nossa região. Esse senso de urgência nos levou a avaliar as atuais políticas e a procurar alternativas viáveis. A abordagem proibicionista, baseada na repressão da produção e criminalização do consumo, claramente, fracassou.

Após 30 anos de esforços maciços, tudo o que o proibicionismo alcançou foi transferir as áreas de cultivo e os cartéis de drogas de um país a outro (conhecido como efeito balão). A América Latina continua sendo a maior exportadora de cocaína e maconha. Milhares de jovens 
continuam a perder as vidas em guerras de gangues. Os barões das drogas dominam comunidades inteiras por meio do medo.

Concluímos nosso informe com a defesa de uma mudança de paradigma. O comércio ilícito de drogas continuará enquanto houver demanda por drogas. Em vez de aferrar-se a políticas fracassadas que não reduzem a lucratividade do comércio - e, portanto, seu poder - precisamos redirecionar nossos esforços à redução do consumo e contra o dano causado pelas drogas às pessoas e sociedade.

A abordagem recomendada no informe da comissão, no entanto, não significa complacência. As drogas são prejudiciais à saúde. Minam a capacidade dos usuários de tomar decisões. O compartilhamento de agulhas dissemina o HIV/Aids e outras doenças. O vício pode levar à ruína financeira e ao abuso doméstico, especialmente de crianças.

Reduzir o consumo ao máximo possível precisa, portanto, ser o objetivo principal. Isso, contudo, requer tratar os usuários de drogas como pacientes que precisam ser cuidados e não como criminosos que devem ser encarcerados. Vários países empenham-se em políticas que enfatizam a prevenção e tratamento, em vez da repressão - e reorientam suas medidas repressivas para combater o verdadeiro inimigo: o crime organizado.

A cisão no consenso global em torno à abordagem proibicionista é cada vez maior. Um número crescente de países na Europa e América Latina se afasta do modelo puramente repressivo.

Portugal e Suíça são exemplos convincentes do impacto positivo das políticas centradas na prevenção, tratamento e redução de danos. Os dois países descriminalizaram a posse de drogas para uso pessoal. Em vez de registrar-se uma explosão no consumo de drogas como muitos temiam, houve aumento no número de pessoas em busca de tratamento e o uso de drogas em geral caiu.

Quando a abordagem política deixa de ser a de repressão criminal para ser questão de saúde pública, os consumidores de drogas ficam mais abertos a buscar tratamento. A descriminalização do consumo também reduz o poder dos traficantes de influenciar e controlar o comportamento dos consumidores. 
Em nosso informe, recomendamos avaliar do ponto de vista da saúde pública - e com base na mais avançada ciência médica - os méritos de descriminalizar a posse da cannabis para uso pessoal.

A maconha é de longe a droga mais usada. Há um número cada vez maior de evidências indicando que seus danos são, na pior hipótese, similares aos provocados pelo álcool ou tabaco. Além disso, a maior parte dos problemas associados ao uso da maconha - desde o encarceramento indiscriminado dos consumidores até a violência e a corrupção associadas ao tráfico de drogas - é resultado das atuais políticas proibicionistas.

A descriminalização da cannabis seria, portanto, um importante passo à frente para abordar o uso de drogas como um problema de saúde e não como uma questão para o sistema de Justiça criminal.

Nenhum país concebeu uma solução abrangente ao problema das drogas. A solução, no entanto, não exige uma escolha cabal entre a proibição e a legalização. A pior proibição é a proibição de pensar. Agora, enfim, o tabu que impedia o debate foi quebrado. Abordagens alternativas estão sendo testadas e precisam ser cuidadosamente avaliadas.

No fim das contas, a capacidade das pessoas de avaliar riscos e fazer escolhas estando informadas será tão importante para regular o uso das drogas quanto leis e políticas mais humanas e eficientes. Sim, as drogas corroem a liberdade das pessoas. É hora, no entanto, de reconhecer que políticas repressivas em relação aos usuários de drogas, baseadas, como é o caso, em preconceito, medo e ideologia, são, da mesma forma, uma ameaça à liberdade. (grifei)

Cabe registrar, finalmente, que a Comissão Interamericana de Direitos Humanos, instituição vinculada à Organização dos Estados Americanos, por sua Relatoria Especial para a Liberdade de Expressão, já manifestou grave preocupação, externada no Informe Anual de 2008, motivada pela existência de decisões judiciais que proibiram, em maio daquele ano, no Brasil, a realização de manifestações públicas que buscavam propor modificações na legislação penal em vigor, assim havendo se pronunciado a respeito, como registra a douta Procuradoria-Geral da República (fls. 05/06): 
50. O Escritório do Relator Especial recebeu informação a propósito da adoção de medidas judiciais em maio de 2008 em nove cidades brasileiras diferentes proibindo a realização de demonstrações públicas que visavam a promover modificações no Direito Penal em vigor. Estas decisões foram justificadas por autoridades judiciais com base no argumento de que elas (as demonstrações públicas) constituiriam supostamente apologia ou instigamento de atividade criminal. O Escritório do Relator Especial recorda que, exceto no caso de formas de expressão que, nos termos do artigo 13 (5) da Convenção Americana, claramente constituam "propaganda de guerra" ou "apologia ao ódio nacional, racial ou religioso que constitua incitamento à violência ilegal ou a qualquer outra ação similar contra qualquer pessoa ou grupo, por qualquer motivo", marchas de cidadãos pacíficos em áreas públicas são demonstrações protegidas pelo direito à liberdade de expressão. (grifei)

\section{Conclusão}

Em suma, Senhor Presidente: a liberdade de expressão, considerada em seu mais abrangente significado, traduz, ela própria, o fundamento que nos permite formular ideias e transmiti-las com o intuito de provocar a reflexão em torno de temas que podem revelar-se impregnados de elevado interesse social.

As ideias, Senhor Presidente, podem ser fecundas, libertadoras, subversivas ou transformadoras, provocando mudanças, superando imobilismos e rompendo paradigmas até então estabelecidos nas formações sociais.

É por isso que se impõe construir espaços de liberdade, em tudo compatíveis com o sentido democrático que anima nossas instituições políticas, jurídicas e sociais, para que o pensamento não seja reprimido e, o que se mostra fundamental, para que as ideias possam florescer, sem indevidas restrições, em um ambiente de plena tolerância, que, longe de sufocar opiniões divergentes, legitime a instauração do dissenso e viabilize, pelo conteúdo argumentativo do discurso fundado em convicções divergentes, a concretização de um dos valores essenciais à configuração do Estado democrático de direito: o respeito ao pluralismo político.

A livre circulação de ideias, portanto, representa um signo inerente às formações democráticas que convivem com a diversidade, vale dizer, com pensamentos antagônicos que se contrapõem, em permanente movimento 
dialético, a padrões, convicções e opiniões que exprimem, em dado momento histórico-cultural, o "mainstream", ou seja, a corrente dominante em determinada sociedade.

É por isso que a defesa, em espaços públicos, da legalização das drogas, longe de significar um ilícito penal, supostamente caracterizador do delito de apologia de fato criminoso, representa, na realidade, a prática legítima do direito à livre manifestação do pensamento, propiciada pelo exercício do direito de reunião, sendo irrelevante, para efeito da proteção constitucional de tais prerrogativas jurídicas, a maior ou a menor receptividade social da proposta submetida, por seus autores e adeptos, ao exame e consideração da própria coletividade.

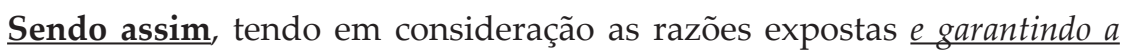
todas as pessoas o exercício dos direitos fundamentais de reunião e de livre manifestação do pensamento, tais como assegurados pela Constituição da República, julgo procedente a presente arguição de descumprimento de preceito fundamental, para dar, ao art. 287 do Código Penal, interpretação conforme à Constituição, "de forma a excluir qualquer exegese que possa ensejar a criminalização da defesa da legalização das drogas, ou de qualquer substância entorpecente específica, inclusive através de manifestações e eventos públicos" (fls. 14 - grifei).

É o meu voto. 